\title{
PENGGUNAAN MEDIA PEMBELAJARAN BERBASIS APLIKASI ANDROID PADA PEMBELAJARAN TEKS EKSPOSISI
}

\author{
Muhamad Riyan \\ Universitas Islam Negeri Syarif Hidayatullah Jakarta \\ email: muhamadriyan20@gmail.com
}

\begin{abstract}
(Title: The Use of Android-based Learning Media on Exposition Text Learning). Learning media is important for the continuity of learning activities so that these activities jave variations that make students not bored. One of them is with android-based learning media. The android-based learning media is form of alignment in the field of education with advances in the field of technology. This study aims to produce android-based learning media as a form of learning variation in exposition texts. In addition, this study also aims to see student responses to android-based learning applications. This research method uses a qualitative descriptive method with interview techniques. The object of this research is an application that is organized according to the subject matter and also a review of this android-based learning application. The results of this study indicate that this android-based learning media application has good feasibility to be used as a variation of new learning media in Indonesian lessons.
\end{abstract}

Keywords: media, learning, android, text, exposition

\section{PENDAHULUAN}

Era revolusi industri 4.0 yang dikenal sebagai pesatnya penciptaan teknologi informasi dan komunikasi yang dimanfaatkan untuk mencapai efesiensi semaksimal mungkin, sehingga teknologi informasi dan komunikasi yang dihasilkan dapat berionvasi menciptakan model baru berbasis digital. Perkembangan teknologi dan komunikasi yang begitu pesat pada saat ini, mendorong guru dan dunia pendidikan untuk menyesuaikan serta menciptakan model media pembelajaran baru berbasis teknologi. Kemajuan teknologi yang sangat pesat dapat membantu guru-guru dan peserta didik dalam melaksanakan kegiatan pembelajaran menjadi efektif dan efesien. Pembuatan media pembelajaran baru berbasis teknologi membuat guru harus mempunyai kemampuan dalam hal mengelola tekno- logi dan kreativitas dalam pembuatan media pembelajaran.

Penggunaan media pembelajaran adalah sesuatu yang penting agar proses belajar tidak terlalu abstrak dan memiliki variasi. Media adalah sebuah komponoen-komponen berbagai jenis yang digunakan di dalam lingkungan peserta didik sebagai alat bantu untuk merangsang kemampuan-kemampuannya di kegiatan pembelajaran (Purba et al., 2020, p. 8). Penggunaan media pembelajaran harus memperhatikan berbagai macam aspek sehingga tujuan pembelajaran menjadi terarah dengan baik. Gagne \& Briggs (Rodhatul, 2009, p. 2) mengungkapkan secara inplisit media pembelajaran meliputi alat-alat yang secara fisik dapat digunakan sebagai pendukung dalam penyampaian pesan atau isi materi pelajaran yang meliputi buku-buku, video, tape recorder, film, salin- 
dia, gambar, komputer, televisi, dan grafik. Penggunaan media pembelajaran harus selaras dengan materi pelajaran yang akan dilaksanakanan. Pemilihan media pembelajaran yang selaras dengan materi pelajaran akan membuat proses kegiatan pembelajaran berjalan efesien dan efektif. Selain itu, dalam pemilihan media harus memperhatikan beberapa aspek yaitu tujuan penggunaan, sasaran penggunaan media, karakteristik media, waktu, biaya, dan ketersediaan (Falahudin, 2014, p. 111).

Perkembangan teknologi yang pesat mendorong pendidikan dituntut selaras dengan kemajuan teknologi. Android merupakan sebuah sistem operasi yang banyak digunakan karena terdapat fitur-fitur yang mudah dipahami oleh pengguna. Selain itu, android sendiri ialah sebuah sistem operasis yang digunakan untuk perangkat mobile berbasis linux yang meliputi sistem operasi, middleware, dan juga aplikasi (D. W. Putra et al., 2016, p. 47). Teknologi bukan merupakan sesuatu yang baru di era saat ini. Penggunaan perangkat mobile seperti smartphone atau tablet merupakan teknologi yang bisa dikatakan sangat dekat dengan peserta didik. Berdasarkan hasil dari market share pada tahun 2013 menunjukan bahwa presentasi gadget telah dikuasai oleh perangkat mobile berbasis android sebesar 81,3\% (Marhadini et al., 2017, p. 29). Pesatnya penggunaan android pada era tersebut dikarenakan dalam android terdapat harga yang terjangkau oleh masyarakat dan juga fitur-fitur yang mudah dipahami oleh pengguna. Kemajuan teknologi tersebut membuat sektor pendidikan harus segera menyesuaikan dan meningkatkan kualitas mutu pendidikan dengan perkembangan teknologi yang sedang berlangsung.

Situasi pembelajaran pada saat Covid-19 ini membuat seluruh Pendidikan di Indonesia memberlakukan pembelajaran jarak jauh
(PJJ). Sebuah inovasi pembelajaran pada masa pandemi ini sebenarnya dapat membuka model pembelajaran baru bagi lembaga pendidkan yang tidak lagi melakukan proses pembelajaran tatap muka di kelas (Ramdani et al., 2020 , p. 434). Pada masa PJJ ini para guru sangat lebih disibukkan dengan kegiatan pemmbelajaran seperti pembuatan bahan ajar, evaluasi peserta didik, dan pelatihan guru-guru, sehingga kesibukkan tersebut membuat rendahnya salah satu keterampilan menulis peserta didik menjadi kurang diperhatikan. Maka dari itu, guru-guru sangat dituntut untuk membuat media-media pembelajaran baru bersis teknologi atau android sebagai variasi bentuk media pembelajaran yang dapat menarik minat menulis peserta didik (Wulandari, 2017, p. 179). Teknologi pada masa pandemic ini sangat memiliki peran yang penting karena dapat membantu proses kegiatan pembelajaran jarak jauh (PJJ) atau daring. Salah satu teknologi yang harus dimanfaatkan yaitu penciptaan media berbasis android dalam kegiatan pembelajaran. Penciptaan ini dapat diselaraskan dengan materi pembelajaran yang akan disampaikan. Pembuatan aplikasi berbasis android sebagai media pembelajaran menjadi alternatif yang tepat dalam pemanfaatan teknologi dan meningkatkan mutu kualitas pendidikan. Aplikasi berbasis android yang diciptakan dapat digunakan dalam kegiatan pembelajaran. Konten-konten yang dibuat dalam aplikasi pembelajaran berbasis android ini berisikan mater-materi pelajaran. Sehingga peserta didik tidak hanya fokus terhadap konten-konten yang menarik tetapi juga dapat memahami pesan atau materi yang disampaikan oleh guru.

Salah satu pelajaran yang bisa digunakan sebagai konten untuk aplikasi pembelajaran berbasis android yaitu pelajaran Bahasa Indonesia. Pelajaran Bahasa Indonesia menjadi pelajaran wajib bagi seluruh jenjang pendidikan 
mulai dari TK hingga perguruan tinggi. Pembelajaran Bahasa Indonesia setidaknya diarahkan untuk dapat menguasai empat keterampilan bahasa yaitu keterampilan menyimak, keterampilan membaca, keterampilan berbicara, dan keterampilan menulis (Nur'aini et al., 2015, p. 2). Materi pelajaran Bahasa Indonesia yang digunakan sebagai konten aplikasi berbasis android salah satu pilihannya yaitu materi "Teks Eksposisi”. Materi tersebut dapat membuat peserta didik dalam memiliki kemampuan kognitif, afektif, dan juga psikomotori. Sedangkan melalui materi teks eksposisi ini peserta didik akan mengerti, memahami, dan meyakini teks bacaan tentang informasi tertentu (Kristyanawati et al., 2019, p. 193). Menulis suatu karangan eksposisi merupakan kegiatan menulis dengan tujuan memaparkan topik secara jelas atau singkat supaya pembaca mendapatkan informasi dan pengetahuan yang disajikan. Karangan yang berfungsi untuk mengupas, mengurai, dan menjelaskan sesuatu disebut sebagai teks eksposisi (Wahyudi et al., 2018, p. 1473). Menulis atau memproduksi teks eksposisi tidak hanya menulis seperti karangan biasa, tetapi diperlukannya pemahaman yang luas agar teks yang dihasilkan sesuai dengan struktur karangan teks eksposisi. Suatu karangan teks eksposisi yang dihasilkan biasanya memiliki paragraph yang digunakan untuk menyajikan pengetahuan atau proses terjadinya sesuatu yang membuat siswa-siswa memiliki pengetahuan tambahan (Alika et al., 2020, p. 224)

Berdasarkan penjelasan yang sudah dipaparkan, maka menciptakan media pembelajaran berbasis android, memerlukan dua hal yaitu pengetahuan guru terhadap teknologi android dan juga kreativitas guru. Penggunaan media berbasis android sebagai langkah untuk meningkatkan kualitas pendidikan yang pada saat ini terus berkembang mengikuti perkembangan zaman. Penggunaan media pembelajaran berbasis android juga bisa dibilang sebagai salah satu cara fleksibel dalam kegiatan pembelajaran.

Penelitian yang relevan pada penelitian ini yaitu berjudul "Media Pembelajaran Berbasis Android Pada Mata Pelajaran Sistem Operasi Jaringan Kelas XI" hasil dari penelitian ini membuktikan bahwa media pembelajaran berbasis android pada mata pelajaran tersebut layak di gunakan sebagai media yang diterapkan di sekolah.

Tujuan pada penelitian ini ingin melihat hasil produksi dan juga menguji cobakan dengan skala kecil terhadap media pembelajaran berbasis android. Selain itu, penelitian ini diharapkan dapat menjadi variasi media pembelajaran Bahasa Indonesia terhadap materi teks eksposisi.

\section{METODE}

Mteode penelitian ini yaitu metode deskriptif yang bersifat kualitatif dengan teknik wawancara. Deskriptif kualitatif adalah Suatu teknik yang mendeskripsikan dan menggambarkan keadaan sebenarnya melalui data-data yang telah dikumpulkan dan diolah untuk memperoleh gambaran secara nyata tentang keadaan yang sebenarnya (Krisyantono, 2007). Objek pada penelitian ini yaitu aplikasi pembelajaran berbasis android pada materi teks eksposisi dan ulasan serta penilaian peserta didik terhadap aplikasi pembelajaran berbasis android tersebut. Data penelitian ini akan menjelaskan bagaimana produk aplikasi pembelajaran berbasis android sebagai variasi media pembelajaran yang digunakan pada materi teks eksposisi dan juga ulasan serta penilaian peserta didik terhadap aplikasi pembelajaran berbasis android (review), sehingga hasil dari penelitian tersebut nantinya sebagai pertimbangan terhadap aplikasi pembelajaran berbasis android. 


\section{HASIL DAN PEMBAHASAN Hasil}

Hasil dari penelitian ini bertujuan untuk menghasilkan inovasi media pembelajaran berupa produk aplikasi pembelajaran berbasis android yang dapat digunakan sebagai media pembelajaran pada materi “Teks Eksposisi”.

Kuswanto membuat beberapa tahap prosedur kerja dalam memproduksi pembelajaran berbasis android, yaitu menganalisis dan mengorganisasi materi, merancang desain dan kemudian mengaplikasikannya kedalam bentuk media pembelajaran berbasis android (Kuswanto \& Radiansah, 2018, p. 17). Aplikasi pembelajaran berbasis android ini dinamakan sesuai dengan materinya yaitu aplikasi Teks Eksposisi.

Aplikasi pembelajaran berbasis android yang digunakan sebagai media pembelajaran memiliki fitur-fitur yang mudah dipahami oleh pengguna. Tujuannya, agar peserta didik dapat mengakses tombol-tombol yang diinginkan. Fitur-fitur tombol tersebut bisa didapatkan di channel You Tube "Guru Berbagi" dan juga di Google.

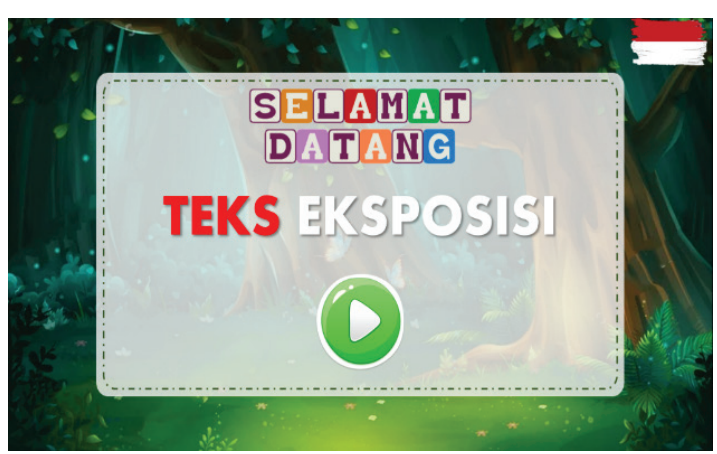

Gambar 1. Tampilan awal

Tampilan awal aplikasi pembelajaran berbasis andorid hanya berisikan 1 tombol Play saja yang terhubung langsung ke halaman menu utama. Selain itu juga ditampilkan beberapa fitur tambahan sebagai penghias tampilan, yaitu berupa background, tulisan materi pembelajaran, ucapan selamat datang, dan juga bendera merah putih.

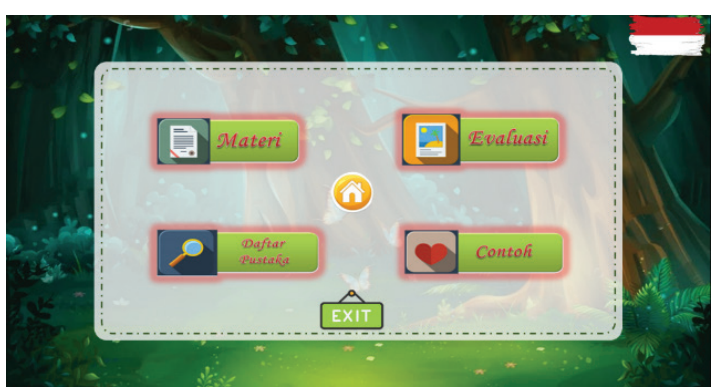

Gambar 2. Halaman Menu

Pada halaman Menu, diisi beberapa fitur tombol-tombol yang terhubung ke tujuan yang diinginkan. Tombol-tombol yang berada di halaman tersebut antara lain tombol Materi, tombol Daftar Pustaka, tombol Evaluasi, tombol Contoh, tombol Home untuk kembali ke tampilan awal, dan tombol exit di pojok kiri atas layar. Tombol exit akan terakses langsung ke tampilan konfirmasi "APAKAH ANDA INGIN KELUAR?”. Jika peserta didik memilih $Y E S$, maka akan keluar dari aplikasi tersebut. Dan jika memilih $N O$, maka akan kembali ke tampilan awal aplikasi.

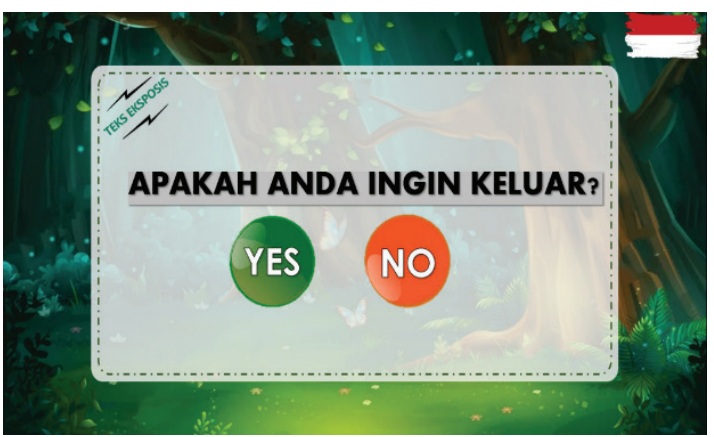

Gambar 3. Tampilan Exit

Halaman Materi berisikan sebuah materi pembelajaran teks Eksposisi yang telah disesuaikan dengan silabus mata pelajaran Bahasa Indonesia. Isi dari tampilan-tampilan materi 
antara lain yaitu pengertian teks eksposisi, pola pengembangan teks eksposisi, struktur kaidah teks eksposisi, kaidah kebahasaan teks eksposisi, dan menyajikan teks eksposisi. Selain itu pada tampilan materi diisi fitur-fitur tombol seperti tulisan teks eksposisi, tombol Kembali, tombol Home, tombol Exit, dan juga tombol Selanjutnya.

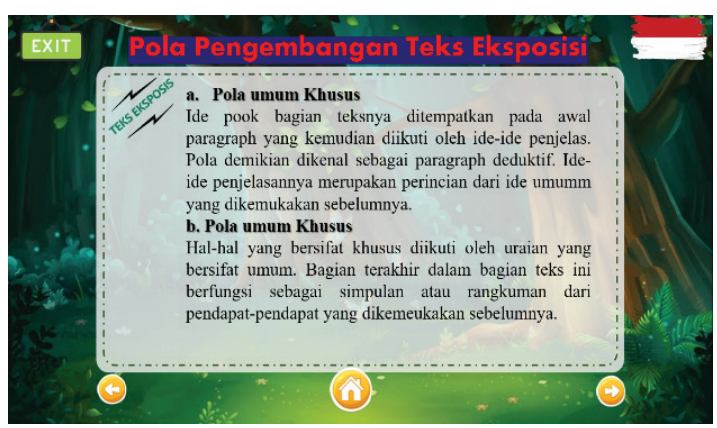

Gambar 4. Tampilan Materi

Halaman daftar Pustaka berisikan daftar-daftar sumber materi pembelajaran teks eksposisi. Sumber tersebut telah disesusaikan dengan silabus yang telah ditetapkan pada pelajaran Teks Eksposisi. Pada halaman tersebut juga dilengkapi satu fitur saja yaitu tombol Home yang dapat terakses kepada tampilan halaman awal aplikasi.

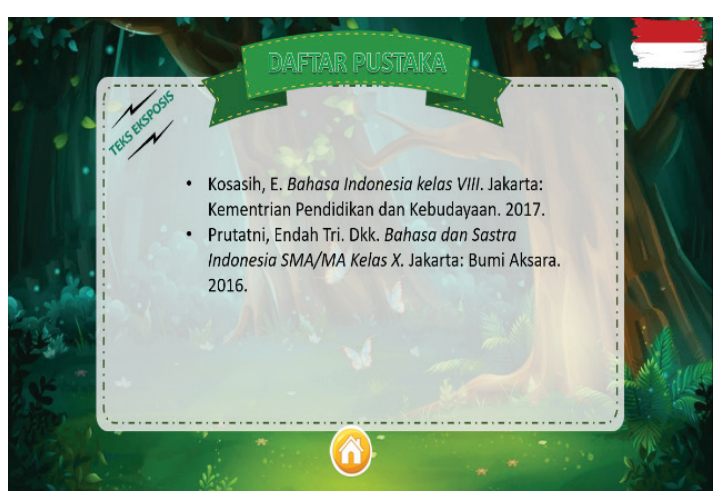

Gambar 5. Tampilan Dafta Pustaka

Tampilan evaluasi berisikan soal-soal sebagai bentuk uji coba kembali peserta didik terhadap pengetahuan materi teks eksposisi. Pada halaman tersebut berisikan 5 butir soal dengan presentasi kelulusan minimal $60 \%$ dengan menjawab soal benar sebanyak 3 butir. Pada tampilan tersebut, peserta didik akan mengetahui langsung jawaban yang dipilihnya benar atau salah. Selain itu juga, peserta didik juga bisa melihat kembali jawaban-jawaban yang benar.

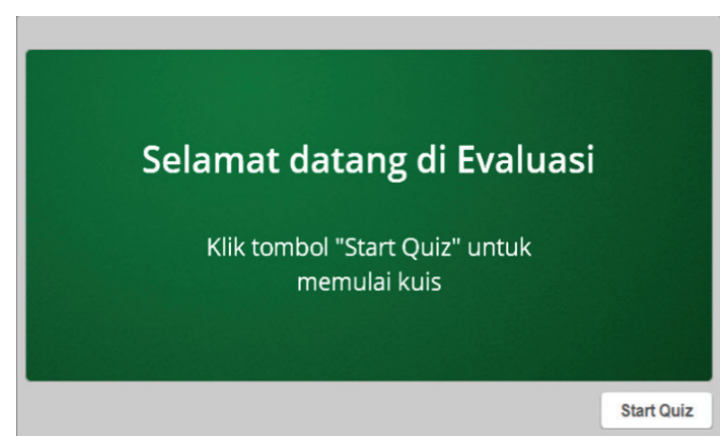

Gambar 6. Tampilan awal Evaluasi

Tampilan awal evaluasi menampilkan tampilan yang sederhana dan hanya berisikan pertanyaan-pertanyaan yang dapat menguji pengetahuan peserta didik terhadap materi teks eksposisi.

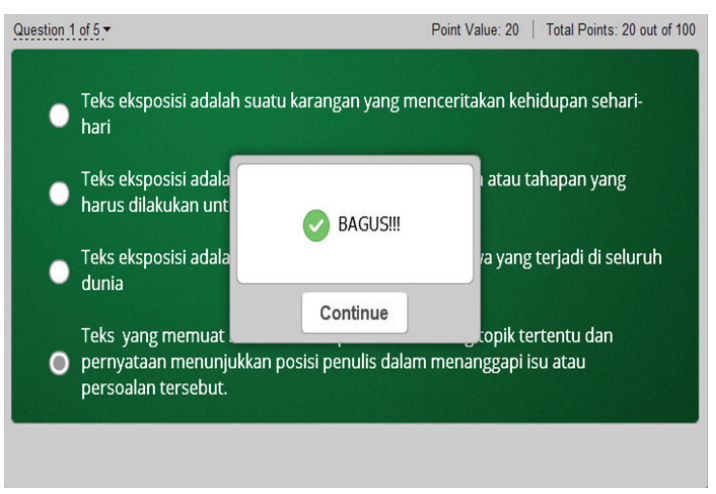

Gambar 7. Tampilan jawaban benar

Pada tampilan evaluasi, peserta didik dapat mengetahui jawaban yang dipilihnya benar atau salah. 


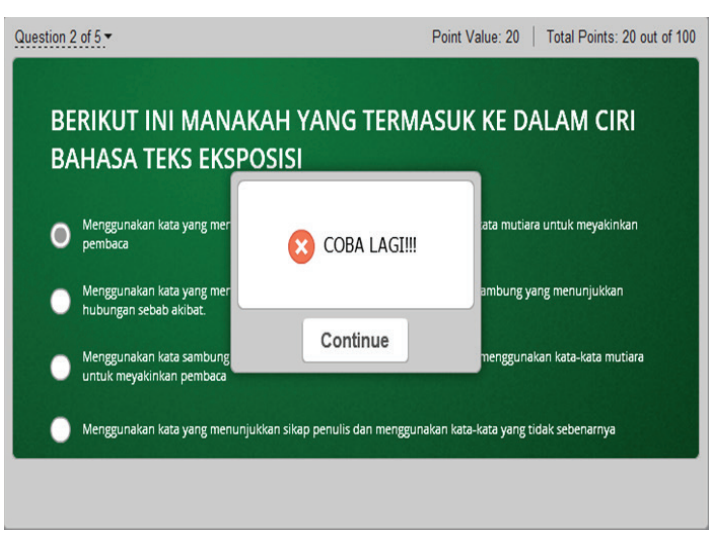

Gambar 8. Tampilan jawaban salah

Ketika jawaban salah, maka akan muncul feedback berupa kata-kata "COBALAGI!!!". Feedback tersebut akan memberikan sinyal kepada peserta didik agar terus berusaha dan mencoba lagi memahami sebuah materi pembelajaran dengan baik.

Dan pada halaman terakhir dari tampilan evaluasi, peserta didik akan mengetahu skor yang didapatnya. Jika berhasil menjawab semua soal dengan jawaban benar maka peserta didik akan mendapatkan perolehan skor 100 .

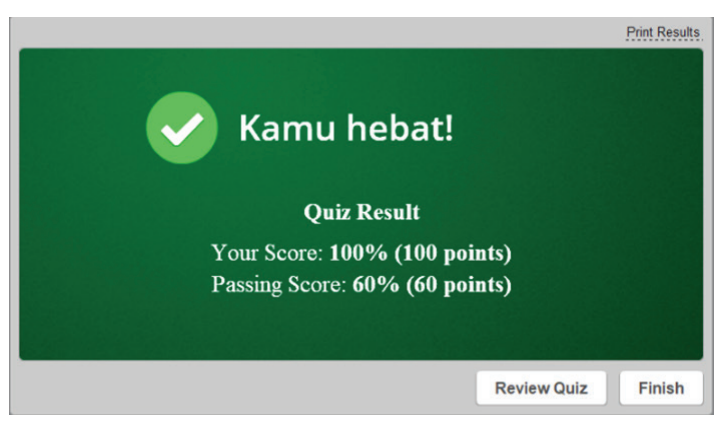

Gambar 9. Tampilan nilai

Halaman terakhir merupakan halaman contoh teks eksposisi yang berjudul kecanduan kopi, sehatkah. Pada halaman tersebut peserta didik diminta untuk membaca sekaligus menyimak teks tersebut, karena teks tersebut nantinya akan menjadi soal evaluasi pada materi teks eksposisi. Soal tersebut berupa perta- nyaan-pertanyaan yang mengulas kembali materi teks eksposisi. Nantinya peserta didik akan mengetahui hasil yang didapat dari evaluasi yang dilakukannya.

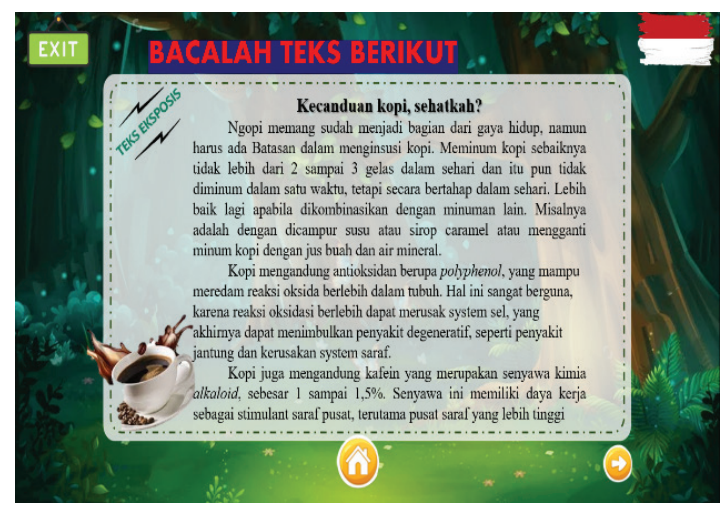

Gambar 10. Tampilan Contoh Materi

Pada halaman tersebut dilengkapi fitur tombol Home dan juga tombol selanjutnya. Selain itu terdapat tombol Exit yang akan terakses ke halaman konfirmasi keluar aplikasi.

\section{PEMBAHASAN}

Pandemi covid-19 yang masih terjadi hingga saat ini memaksakan seluruh sektor-sektor yang ada untuk bertahan dan juga meningkatkan kualitasnya. Sektor pendidikan pada saat pandemi ini masih menjadi persoalan dalam meningkatkan kualitas sistem pendidikan. Berbagai upaya dalam meningkatkan kualitas sistem pendidikan telah dilakukan mulai dari seluruh komponen-komponen pendidikan, upaya peningkatan kualitas pengajar, bahan ajar dan sarana belajar, sistem pembelajaran, upaya penyempurnaan sistem, dan juga pengelolaan organisasi dan manajemen pendidikan (Pitoyo, 2020, p. 171). Dalam hal ini guru harus dapat mengelola perkembangan iptek untuk memfasilitasi kegiatan pembelajaran peserta didik seperti mengelola metode pembalajaran, media pembelajaran, dan juga sarana prasarana yang diperlukan dalam memu- 
dahkan peserta didik (Musfiroh \& Endaswara, 2015 , p. 23). Kualitas mutu pembelajaran dibagi dari dua segi yaitu segi proses dan hasil pembelajaran (Husain, 2014, p. 184). Maka dari itu, peningkatan mutu kualitas pendidikan bisa dilakukan dengan pemanfaatan teknologi melalui penciptaan aplikasi pembelajaran berbasis android oleh guru-guru atau penggiat pendidikan yang dapat menarik minat peserta didik dalam kegiatan pembelajaran.

Sebuah aplikasi pembelajaran berbasis android ini merupakan sebagai bentuk variasi media pembelajaran pada materi teks eksposisi. Pendidikan pada situasi Covid-19 ini dilaksanakan dengan pemebelajaran jarak jauh. Bidang pendidikan dan juga guru diharuskan menciptakan media-media pembelajaran baru yang membuat kegiatan pembelajaran jarak jauh agar terlihat memiliki variasi dan tidak membosankan. Para guru tidak harus selalu menggunakan media pembelajaran yang sudah seperti PPT, Whatsapp, Google Clasroom, dll. Tetapi para guru juga bisa memanfaatkan teknologi-teknologi lain dan menciptakan media pembelajaran baru. Salah satu contohnya yaitu memanfaatkan perkembangan teknologi saat ini, misalnya saja dengan menciptakan sebuah perangkat aplikasi berbasis android. Gawai berbasis android merupakan alat teknologi yang sangat dekat dengan peserta didik. Peserta didik yang saat ini lebih dikenal sebagai generasi $\mathrm{Z}$ memanfaatkan gawai sebagai media untuk berinteraksi, berkegiatan sosial, bahkan sekedar untuk mencari hiburan. Gawai berbasis android sangat digandrungi karena memiliki fitur-fitur yang mudah digunakan dan juga memiliki harga yang dapat terjangkau dibandingkan dengan gawai jenis lain yang tidak berbasis android. Pemanfaatan teknologi gawai atau smartphone memiliki pengaruh terhadap peserta didik karena gawai atau smartphone sangat praktis digunakan se- bagai media pembelajaran (R. S. Putra et al., 2017, p. 2010).

Aplikasi pembelajaran berbasis android digunakan sebagai inovasi pembelajaran Bahasa Indonesia pada materi "Teks Eksposisi". Selain itu, aplikasi pembelajaran berbasis android ini digunakan sebagai dukungan penyampaian materi pembelajaran oleh guru dalam memudahkan pemahaman siswa tentang materi yang disampaikan. Penyampaian pesan atau informasi materi pembelajaran merupakan tujuan utama dalam kegiatan pembelajaran. Pesan yang tersampaikan oleh guru harus dipahami oleh peserta didik. Dalam mendukung penyampaian pesan atau materi pembelajaran memerlukan dukungan media yang menarik dan disesuaikan dengan generasi dan situasi saat ini. Selaras dengan pernyataan tersebut bahwa perencanaan media pembelajaran harus memperhatikan beberapa aspek yaitu media pembelajaran dapat disesuaikan dengan karakter siswa, dapat merumuskan tujuan pembelajaran, media pembelajaran mampu merumuskan materi ajar, membuat tolak ukur sebuah media pembelajaran, melakukan tes dan revisi (Budiyono, 2020, p. 301).

Pembelajaran Jarak Jauh (PJJ) membuat guru-guru hanya menggunakan media pembelajaran yang sama saat digunakan pada pembelajaran normal atau langsung, misalnya menggunakan media power point untuk menjelaskan materi pembelajaran. Media power point memiliki fitur-fitur sederhana yang terkadang membuat peserta didik bosan ketika menggunakannya untuk belajar atau membaca materi pembelajaran. Maka dari itu, diperlukan trobosan baru berupa media pembelajaran yang inovatif dan kreatif. Salah satu media tersebut adalah dengan membuat aplikasi pembelajaran berbasis android. Aplikasi pembelajaran berbasis android tersebut sebagai bentuk keselarasan bidang pendidikan terhadap kemajuan teknolo- 
gi. Kemajuan teknologi menuntut bidang pendidikan untuk berinovasi dalam melaksanakan kegiatan Pembelajaran. Membuat aplikasi berbasis android tidak terlalu membutuhkan biaya karena terdapat aplikasi-aplikasi gratis untuk membuat sebuah aplikasi. Selain itu juga dalam membuat sebuah aplikasi, dibutuhkan kreatifitas dan kemampuan penggunaan teknologi yang memadai. Dalam membuat aplikasi pembelajaran ini diperlukannya pengembangan aplikasi media pembelajaran agar dapat dimanfaatkan secara berkala dalam kegiatan pembelajaran. Pengembangan media pembelajaran dibagi menjadi tiga model meliputi (1) model prosedural, model ini merupakan model yang bersifat deskriptif, (2) model konseptual, model ini merupakan model yang bersifat analitis, (3) model teoritik, model ini ialah model yang menunjukkan hubungan perubahan antar peristiwa (Musfiroh \& Endaswara, 2015, p. 24).

Aplikasi pembelajaran yang digunakan sebagi media pembelajaran harus melibatkan peserta didik. Sedangakan aplikasi itu tersendiri ialah sebuah perangkat lunak yang diciptakan dan digunakan untuk tujuan tertentu misalnya seperti pengelolaan dokumen, windows, dan bahkan permaian (Neyfa \& s Salsabila, 2016, p. 85). Sebuah aplikasi memiliki tujuan untuk melibatkan peserta didik dalam kegiatan pembelajaran yaitu agar tujuan pembelajaran yang telah dirancang menjadi mudah dicapai. Serta kegiatan pembelajaran menjadi lebih interaktif, efektif, dan efesien. Selain itu, juga dapat mengasah kemampuan peserta didik dalam kegiatan pembelajaran. Kemampuan-kemampuan yang harus dimiliki peserta didik dalam dunia pendidikan setidaknya ada tiga kemampuan yaitu (1) kemampuan kognitif, (2) kemampuan afektif, dan (3) kemampuan psikomotor. Kemampuan-kemampuan tersebut harus didorong dengan media-media pembelajaran yang secara langsung dapat melibatkan peserta didik dalam kegiatan pembelajaran. Keterlibatan peserta didik merupakan hal yang terpenting dalam kegiatan pembelajaran. Pernyataan tersebut selaras dengan sepuluh kerucut pengalaman yang dikemukakan oleh Edgar Dale yaitu (1) verbal, (2) visual, (3) 1 visual verbal, (4) verbal, visual, dan gerak, (5) pameran, (6) studi wisata, (7) demonstrasi, (8) dramatisasi, (9) pengalaman tiruan, dan (10) pengalaman langsung (Soeparno, 1988, p. 5). Penciptaan aplikasi pembelajaran berbasis android ini bertujuan agar peserta didik menjadi lebih interaktif. Cole \& Todd (Ramdani et al., 2020, p. 435) mengemukakan bahwa media interaktif memiliki dampak positif bagi peserta didik dalam meningkatkan minat belajarnya yang dilihat dari hasil evaluasi dan aktivitas kegiatan pembelajaran yang baik. Penciptaan media pembelajaran berbasis android lebih mengedepankan konten-konten menarik yang berisikan materi pembelajaran agar peserta didik lebih fokus dan tidak bosan dalam menggunakan aplikasi pembelajaran berbasis android.

Penciptaan aplikasi pembelajaran berbasis android ini memiliki tentu saja memiliki tujuan yang diselaraskan dengan tujuan pembelajaran. Dalam menciptakan sebuah aplikasi pembelajaran berbasis android ini harus memiliki tiga syarat wajib yang dipenuhi yaitu sederhana, personal, dan cepat (Yazdi, 2012, p. 147). Pemilihan operasi sistem berbasis android telah dipertimbang oleh peneliti. Pertimbangan tersebut meliputi (1) gawai berbasis android banyak digunakan oleh peserta didik, (2) terdapat aplikasi pendukung gratis dalam pembuatan aplikasi berbasis android, (3) pembuatan aplikasi berbasis android mudah dilakukan karena terdapat banyak tutorial yang terdapat di internet. Aplikasi yang diciptakn tidak memerlukan internet dan hanya memerlukan sebuah ruangan memori yang tidak ter- 
lalu memberatkan gawai peserta didik. Internet menjadi persoalan dalam pembelajaran jarak jauh (PJJ). Banyak peserta didik yang merasa keberatan apabila kegiatan pembelajaran selalu menggunakan internet yang terlalu banyak memakan kuota data internet. Maka dari itu, penciptaan aplikasi pembelajaran berbasis android ini tidak terlalu membutuhkan internet pada saat menggunakan aplikasi. Tetapi, aplikasi ini harus diunduh terlebih dahulu sebelum menggunakannya.

Media yang diproduksi oleh peneliti ini dinamakan Teks Eksposisi sesuai dengan materi yang akan dipelajari di sekolah. Media tersebut memang belum diuji coba secara skala besar, misalnya diuji cobakan kepada ahli ataupun guru yang mengajar pelajaran Bahasa Indonesia. Pengujian aplikasi tersebut hanya dilakukan oleh peneliti dengan skala kecil, yaitu dengan mengambil 5 responden yang berstatus sebagai peserta didik dan telah belajar teks eksposisi. Uji coba tersebut untuk melihat kelayakan sebuah media pembelajaran berbasis android ketika digunakan di sekolah-sekolah.

Pada penelitian ini menggunakan teknik wawancara terhadap peserta didik. Uji coba tersebut untuk melihat kelayakan sebuah aplikasi pembelajaran berbasis android. Responden tersebut nantinya akan memberikan ulasan dan juga penilaian (rating) terhadap media pembelajaran berbasis android pada materi teks eksposisi. Peneliti menetapkan penilaian terhadap aplikasi pembelajaran berbasis android tersebut berupa bintang 1-5. Ratio penilaian bintang 1 termasuk kategori sangat buruk, bintang 2 termasuk kategori buruk, bintang 3 (baik), bintang 4 (cukup baik), bintang 5 (sangat baik). Ulasan-ulasan dan penilaian terhadap aplikasi pembelajaran berbasis android itu nantinya akan digunakan sebagai pertimbangan kelayakan terhadap aplikasi pembelajaran.
Berdasarkan survei yang peneliti lakukan berjumlah lima responden. Responden-responden tersebut memberikan tanggapan positif terhadap aplikasi pembelajaran berbasis android tersebut. Responden tersebut memberikan tanggapan bahwa media pembelajaran berbasis android yang peneliti tawarkan amat menarik jika diterapkan dalam materi pembelajaran Bahasa Indonesia yaitu "Teks Eksposisi”. Tanggapan tersebut dilatarbelakangi karena media pembelajaran yang peneliti tawarkan merupakan media pembelajaran yang masih terbilang baru, yang pastinya amat menarik untuk diterapkan di kelas pada saat pembelajaran Bahasa Indonesia dengan materi teks eksposisi. Selain itu, penggunaan media berbasis android ini akan membuat peserta didik tidak bosan selama pembelajaran berlangsung, sebab tampilan-tampilan yang ditawarkan menarik dan penuh warna, disertai fitur-fitur yang membantu proses pembelajaran di kelas. Peserta didik memberikan penilaian terhadap aplikasi pembelajaran tersebut berupa bintang 3, 4, dan 5 dengan kategori baik, cukup baik, dan sangat baik. Berikut adalah Ulasan dan penilaian peserta didik terhadap media pembelajaran berbasis android pada materi "Teks Eksposisi":

1. Responden pertama memberikan tanggapan yang sangat positif terhadap aplikasi tersebut. Responden tersebut memberikan tanggapan bahwa aplikasi ini sangat perlu dikembangkan sebagai media pembelajaran. Karena bagi responden aplikasi ini sebagai bentuk variasi baru untuk menggantikan power point dan juga buku elektronik sebagai media pembelajaran. Selain itu, ia memberikan ide agar aplikasi tersebut perlu ditambahkan fitur-fittur berupa permaian sebagai bentuk variasi terhadap tampilan evaluasi pada materi teks eksposisi. Penilaian yang diberikan 
responden terhadap aplikasi tersebut yaitu bintang 4 dengan kategori cukup baik.

2. Responden yang kedua memberikan tanggapan yang sama yaitu positif. Ia memberikan tanggapan bahwa aplikasi ini perlu dikembangkan sebagai media pembelajaran baru. Karena pada situasi pembelajaran jarak jauh diperlukannya media-media pembelajaran baru yang menarik agar peserta didik memiliki antusias dalam pembelajaran jarak jauh. Penilaian terhadap aplikasi tersebut yaitu bintang 3 dengan kategori baik.

3. Responden ketiga memberikan tanggapan yang positif yaitu pendapat tentang aplikasi ini memiliki inovasi dan variasi dalam kegiatan pembelajaran. Selain itu, aplikasi pembelajaran ini dapat memudahkan peserta didik dalam mengakses materi Teks Eksposisi. Responden ketiga memberikan bintang 4 dengan kategori cukup baik untuk aplikasi pembelajaran berbasis android ini.

4. Responden keempat memberikan tanggapan baik berupa pendapatnya tentang aplikasi pembelajaran ini. Ia berpendapat bahwa aplikasi ini perlu dikembangkan agar materi-materi pembelajaran Bahasa Indonesia tidak hanya berisikan satu materi saja. Responden tersebut memberikan bintang tiga dengan kategori baik untuk aplikasi.

5. Responden kelima memberikan tanggapan positif yang menyatakan bahwa aplikasi pembelajaran ini harus dikembangkan dengan fitur-fitur yang menarik dan materi pembelajaran Bahasa Indonesia yang lain. Sehingga aplikasi ini tidak hanya berisikan materi Teks Eksposisi saja. Responden terakhir ini memberikan bintang 3 untuk aplikasi pembelajaran tersebut.
Sebagai bentuk media pembelajaran berbassi android pada pelajaran Bahasa Indonesia khususnya materi teks eksposisi, tentunya memiliki kelebihan dan kekurangan masing-masing. Kelebihan pada aplikasi pembelajaran berbasis android ini yaitu:

1. Dapat mudah digunakan karena terdapat fitur-fitur yang mudah dipahami bagi peserta didik.

2. Dapat diakses dimana saja dan kapan saja.

3. Dapat diakses dengan internet ataupun tidak.

Selain kelebihan yang dimiliki, tentunya terdapat kekurangan yang terdapat di aplikasi pembelajaran berbasis android tersebut. Antara lain yaitu:

1. Harus membutuhkan gadget android berupa handphone atau tab.

2. Isi aplikasi berupa materi pembelajaran saja yang bisa membuat pengguna khususnya peserta didik merasa bosan.

3. Produk aplikasi hanya berupa pelajaran Bahasa Indonesia khususnya materi teks eksposisi.

\section{PENUTUP}

Bentuk sebuah aplikasi pembelajaran yang dihasilkan adalah sebagai bentuk media pembelajaran baru berbasis android pada materi teks eksposisi. Produk media pembelajaran yang dihasilkan berupa tampilan gambar, fitur-fitur tombol yang bisa diakses sesuai keinginan, dan juga materi-materi teks eksposisi yang telah disesuaikan dengan silabus Bahasa Indonesia. Media pembelajaran berbasis android tersebut sebagai bentuk variasi terhadap pelajaran Bahasa Indonesia khususnya pada materi teks eskposisi, sehingga peserta didik dapat antusias mengikuti kegiatan belajar. Media pembelajaran ini telah diuji coba secara sederhana dengan skala kecil untuk melihat 
tanggapan-tanggapan peserta didik apabila terdapat media pembelajaran berbasis android sebagai bentuk media baru dalam pelajaran Bahasa Indonesia. Dari data keseluruhan responden yang dilakukan uji coba kelayakan, semuanya memiliki tanggapan yang positif dengan kategori "baik". Selain itu juga memberikan tanggapan lain berupa ide-ide untuk mengembangkan media pembelajaran berbasis android tersebut. Sebuah prodak pembelajaran berbasis android ini memiliki kelebihan dan kekurangannya masing-masing. Maka dari itu aplikasi ini perlu dikembangkan untuk meningkatkan kualitas aplikasi pembelajaran berbasis android ini sebelum digunakan di sekolah-sekolah. Sehingga ketika aplikasi pembelajaran berbasis android ini digunakan di sekolah dapat terlihat sangat menarik dan maksimal.

\section{DAFTAR PUSTAKA}

Alika, A. C. N., Handayani, H., Badriah, I., Hartinah, K. S., \& Sisilawati, S. (2020). Profil Kemampuan Membaca Pemahaman Siswa Kelas X Terhadap Materi Teks Eksposisi. PROCEEDINGS UNIVERSITAS PAMULANG.

Budiyono, B. (2020). Inovasi Pemanfaatan Teknologi Sebagai Media Pembelajaran di Era Revolusi 4.0. Jurnal Kependidikan: Jurnal Hasil Penelitian Dan Kajian Kepustakaan Di Bidang Pendidikan, Pengajaran Dan Pembelajaran, 6(2), 300-309.

Falahudin, I. (2014). Pemanfaatan media dalam pembelajaran. Jurnal Lingkar Widyaiswara, 1(4), 104-117.

Husain, C. (2014). Pemanfaatan teknologi informasi dan komunikasi dalam pembelajaran di SMA Muhammadiyah Tarakan. Jurnal Kebijakan Dan Pengembangan Pendidikan, 2(2).
Kristyanawati, M. D., Suwandi, S., \& Rohmadi, M. (2019). Peningkatan Keterampilan Menulis Teks Eksposisi Menggunakan Model Problem Based Learning. Scholaria: Jurnal Pendidikan Dan Kebudayaan, 9(2), 192-202.

Krisyantono, R. (2007). Teknik Praktif Riset Komunikasi. Kencana.

Kuswanto, J., \& Radiansah, F. (2018). Media Pembelajaran Berbasis Android Pada Mata Pelajaran Sistem Operasi Jaringan Kelas XI. Media Infotama, 16(2). https:// doi.org/https://doi.org/10.37676/jmi. v14i1.467

Marhadini, S. A. K., Akhlis, I., \& Sumpono, I. (2017). Pengembangan media pembelajaran berbasis android pada materi gerak parabola untuk siswa sma. UPEJ Unnes Physics Education Journal, 6(3), 38-43.

Musfiroh, T., \& Endaswara, S. (2015). Pengembangan Media Pembelajaran Bahasa Berbasis Lingkungan dan Teknologi. Diksi, 23(1).

Neyfa, B. C., \& s Salsabila, G. (2016). Perancangan Aplikasi E-Canteen Berbasis Android Dengan Menggunakan Metode Object Oriented Analysis \& Design (OOAD). Jurnal Penelitian Komunikasi Dan Opini Publik, 20(1).

Nur'aini, H. I. M., Saddhono, K., \& Ulya, C. (2015). Implementasi kurikulum 2013 pada pembelajaran menulis teks eksposisi (studi kasus di kelas x smk negeri 1 karanganyar). BASASTRA, 3(3).

Pitoyo, A. (2020). PEMBELAJARAN KETERAMPILAN BERBAHASA PRODUKTIF BERBASIS COOPERATIVE LEARNING: SEBUAH EKSPERIMEN MODEL PEMBELAJARAN BRAIN DAN INVESTIGASI KELOMPOK. Diksi, 28(2), 171-178. 
Purba, R. A., Rofiki, I., Purba, S., Purba, P. B., Bachtiar, E., Iskandar, A., Febrianty, F., Yanti, Y., Simarmata, J., \& Chamidah, D. (2020). Pengantar Media Pembelajaran. Yayasan Kita Menulis.

Putra, D. W., Nugroho, A. P., \& Puspitarini, E. W. (2016). Game Edukasi berbasis android sebagai media pembelajaran untuk anak usia dini. JIMP-Jurnal Informatika Merdeka Pasuruan, 1(1).

Putra, R. S., Wijayati, N., \& Mahatmanti, F. W. (2017). Pengaruh penggunaan media pembelajaran berbasis aplikasi android terhadap hasil belajar siswa. Jurnal Inovasi Pendidikan Kimia, 11(2).

Ramdani, A., Jufri, A. W., \& Jamaluddin, J. (2020). Pengembangan Media Pembelajaran Berbasis Android pada Masa Pandemi Covid-19 untuk Meningkatkan Literasi Sains Peserta Didik. Jurnal Kependidikan: Jurnal Hasil Penelitian Dan
Kajian Kepustakaan Di Bidang Pendidikan, Pengajaran Dan Pembelajaran, 6(3), 433-440.

Rodhatul, J. (2009). Media Pembelajaran. Banjarmasini Press.

Soeparno. (1988). Media Pengajaran Bahasa. Intan Parawira.

Wahyudi, S. A., Nurhadi, N., \& Pratiwi, Y. (2018). Bahan ajar teks eksposisi berbasis kearifan lokal. Jurnal Pendidikan: Teori, Penelitian, Dan Pengembangan, 3(11), 1472-1476.

Wulandari, A. (2017). STUDI KOMPARASI ANTARA STRATEGI QUIP DAN STRATEGI INFORMATION CHARTS DALAM PEMBELAJARAN MENULIS TEKS EKSPOSISI. Diksi, 25(2).

Yazdi, M. (2012). E-learning sebagai media pembelajaran interaktif berbasis teknologi informasi. Jurnal Ilmiah Foristek, 2 (1). 